\author{
В. Л. Макаров, А. Н. Козырев, В. Е. Дементьев \\ Центральный экономико-математический институт РАН, \\ Москва, Россия \\ Е. В. Устюжанина \\ Российский экономический университет имени Г. В. Плеханова, \\ Центральный экономико-математический институт РАН, \\ Москва, Россия
}

В статье рассматриваются проблемы трансформации института государства в современных условиях. Особое внимание уделено следующим вопросам: определяющие признаки государства как особого социальноэкономического института; имманентные противоречия данного института; направления развития государства в условиях глобализации мирохозяйственных связей, цифровизации системы коммуникаций и экологической взаимозависимости. Особенностью подхода к исследованию является концентрация внимания на экономических аспектах происходящих изменений. Цель статьи - выявление основных проблемных точек взаимного воздействия государства и экономической системы. Авторами обсуждаются такие проблемы, как переформатирование системы связей внутри и между государствами, роль государства в контроле над ключевыми ресурсами, двойственный характер государства как института, размывание границ государства, гражданство в условиях космополизации, возможность существования такой формы организации общественной жизни, как народовластие, роль культуры в формировании и сохранении института государства, воздействие пандемии на эволюцию межгосударственных отношений. Мнения соавторов публикации совпадают далеко не по всем вопросам, вместе с тем их объединяет общий подход к исследованию феномена государства как развивающегося и трансформирующегося института. Статья написана по материалам научного семинара, который проходил в Центральном экономико-математическом институте РАН в рамках дискуссионного клуба «Макаровские посиделки».

Киюевые слова: государство, правительство, признаки государства, суверенитет, народовластие, цифровизация, глобализация, контроль над ресурсами, сетевые структуры.

\title{
STATE VIEWED BY ECONOMISTS
}

\author{
Valery L. Makarov, Anatoly N. Kozyrev, Viktor E. Dementiev \\ Central Economics and Mathematics Institute of RAS, \\ Moscow, Russia \\ Elena V. Ustyuzhanina \\ Plekhanov Russian University of Economics, \\ Central Economics and Mathematics Institute of RAS, \\ Moscow, Russia
}

\begin{abstract}
The article studies issues of transforming the institution of state in today's conditions. Special attention is paid to the following questions: characteristic features of state as a specific social and economic institution; immanent contradictions of the institution; lines in state development in conditions of world economic ties globalization; digitalization of the communication system and ecological interdependence. The given approach to research is characterized by its focus on economic aspects of current changes. The goal of the article is to find out key spots of mutual impact of state and economic system. The authors discuss such problems as reshaping the system of contacts inside state and among them, the role of state in controlling key resources, dubious nature of state as an institution, watering state borders, citizenship in conditions of cosmopolitanism, feasibility of such form of public life organization as people's rule, the role of culture in forming and retaining the institution of state, the impact of pandemia on evolution of interstate relations. Co-authors' opinions are not always the same, however, they adhere to the common approach to researching the phenomenon of state as a developing and transforming institution. The article was written on the basis of materials of the seminar held in the Central Institute of Economics and Mathematics RAN within the frames of the 'Makarov's Gathering' Club.
\end{abstract}


Keywords: state, government, state features, sovereignty, government by people, digitalization, globalization, resource controlling, network structures.

\section{Макаров Валерий Леонидович}

$r$ волюция человеческой цивилизации идет в направлении увеличения связей между людьми, группами лиц, организациями, в том числе государствами. Научно-технический прогресс приводит к тому, что разнообразие таких связей возрастает, особенно в последнее время. Например, П. Ханна написал большую книгу, посвященную всем видам связей в современном обществе [9].

Государство в современном смысле ассоциируется с родовой, национальной и местной идентичностью. Поэтому истинные государства, определенные по данному принципу, являются относительно небольшими. Патриотизм, любовь к Родине не распространяются на большие империи.

Как показывают статистические данные, количество государств, в частности зарегистрированных в ООН, постоянно и довольно быстро растет. Империи распадаются. Вместо СССР появилось более пятнадцати государств, вместо Югославии семь. Кто может поручиться, что Каталония, баски, Шотландия, бельгийские районы и прочие во всех частях земного шара не получат государственную независимость. Тенденция налицо.

В связи с этим все большее распространение получают разнообразные союзы государств: ЕС, НАТО, ШОС, БРИКС и им подобные. В них имеются свои управляющие органы, правила поведения, законы. Указанные союзы не имеют четкой причины или основы своего возникновения, как в случае с национальными государствами. Причины могут быть разные: идеологическая, пространственная, религиозная, культурно-историческая.

С помощью подобных союзов, а также международных договоров самого разного толка подкрепляется деятельность, особенно экономическая, многообразных международных корпораций. Продукто- вые цепочки охватили весь мир. Их становится все больше и больше. Глобализация в экономической сфере неизбежна. В связи с этим проблема обеспечения государственного суверенитета приобретает новые краски. Идут разговоры о политическом, экономическом, культурном, научном суверенитете, где есть свои особенности.

Рассмотрим в качестве примера вопрос о собственности. Собственность фиксируется множеством национальных и международных законов. В частности, за нее надо платить налоги. Мы наблюдаем многочисленные примеры манипуляций с собственностью, которые, как говорится, сходят с рук. Например, здание, находящееся в собственности посольства России в США, захватили американские службы; росчерком пера была распределена собственность СССР по странам, не говоря уже о модной ныне системе санкций.

Не случайно в принятых недавно поправках в Конституцию Российской Федерации единодушно вставили поправку о приоритете национальных законов над международными. Суверенитет становится более значимым, чем раныше.

Возникает естественный вопрос: а как будет развиваться человечество дальше? Не объявит ли каждая деревня себя государством со своими законами и всем прочим. Здесь надо в первую очередь вспомнить историю. Сначала примерно так и было. Племена жили отдельно по своим законам. Потом они постепенно стали объединяться, в частности, из-за необходимости производить общественные блага (армию, флот, крепости и пр.). Этот процесс дошел до тотальной колонизации, до империй разных типов, таких как Римская, Византийская, Османская, Российская, Американская. Теперь мы наблюдаем обратный процесс: количество национальных государств увеличивается. Ясно, что этот процесс скоро остановится, хотя бы 
вследствие технического прогресса. Тотальная цифровизация неизбежна. Деятельность компаний - производителей продукции, банков, управляющих и контрольных органов принципиально изменится. Даже местоположение, место работы, гражданство станут фиксироваться подругому. Но понятие государства, как и национальности, сохранится. Человечество не может развиваться без сохранения культуры, языка, религии, идеологии, что напрямую связано с существованием различных групп. Это клубы по интересам, местоположению, проживанию и т. д.

При этом ясно, что понятие государства тоже развивается, корректируется. Человечество производит разные коллективные блага, без которых его существование невозможно. А государство производит такие общественные блага, при которых человек чувствует себя человеком в ощущении безопасности, справедливости, своей значимости для других. Поэтому пока существует человечество, существует и государство. В связи с этим стоит заметить, что когда К. Маркс говорил об отмирании государства, то он понимал его в узком смысле, похожем на своеобразного жандарма, ограничивающего индивидуальные свободы.

\section{Козырев Анатолий Николаевич}

Есть ии у государства как института определяющий признак, отличающий его от других институтов? Может быть, совокупность признаков?

Ключевой признак государства - монополия на легитимное насилие. Территория играет роль «рамки», поскольку монополия ограничена территорией. Если бы существовало мировое правительство, про территорию можно было не вспоминать, как никто пока не вспоминает про плату за воздух.

Как соотносятся между собой две функции государства: производство общественных благ и принуждение?

Производство общественных благ возможно без принуждения. Это всегда имело место в малых группах (семья, дружеская компания, клуб единомышленников) или определенных социальных стратах. Например, капитаны кораблей могли добровольно платить за сигнал маяка, а многие программисты делают великолепный софт для всех. Самый яркий пример - Дональд Кнут сделал ТеХ. Но расширение круга участников быстро наталкивается на недобросовестное поведение, почему-то именуемое оппортунистическим.

В каком направлении происходит эволюиия государства? В эпоху изифровизации и глобализации государства укрепляются или начинают модифицироваться $b$ сторону сохранения формы при потере содержания?

Эволюция происходит в направлении высвечивания болячек, обозначенных выше. А потому государства неизбежно будут двигаться в сторону, указанную когда-то Дж. Оруэллом. Ситуация с коронавирусом - одно из свидетельств этой тенденции. Впрочем, и без нее все было ясно тем, кто следит «за руками».

Возможен ми такой принцип управления, как народовластие?

В коллективе до 7 человек - да, но не всегда и не полностью. А при увеличении числа агентов возможность уменьшается довольно быстро.

Насколько серьезно пандемия изменила систему политических и экономических отношений между государствами?

Пока пандемия показала, что слежка за гражданами с помощью электронных средств позволяет быстро подавить вспышку заболеваний. Самые яркие примеры - Южная Корея и Сингапур. Про Сингапур почти не пишут, поскольку там с самого начала все подозрительные получили браслеты с датчиками и находились под жестким контролем. Правда, потом карантин все же ввели, поскольку имела место вспышка заболеваний среди рабочих. Но, судя по всему, они быстро справились. А в Южной Корее была сильная вспышка сразу, писали о ней много, но она подавлена и тоже благодаря наличию устройств у 100\% граждан. Противоположный пример - США, где свобода превыше всего, и отчасти Россия, где стара- 
тельно собирают людей в толпы на входе в метро.

Про число государств что-то определенное сказать сложно, поскольку процесс идет к бифуркации (как минимум): либо мировое правительство со всеобщей слежкой, либо откат назад в раздробленность и сжигание ученых на чем-нибудь горячем. Но можно и просто все угробить. Помимо коронавируса есть много других проблем, в том числе пресловутые восемь смертных грехов цивилизованного человечества, отмеченных Конрадом Лоренцем [4], к которым добавляется девятый - искусственный интеллект.

\section{Дементьев Виктор Евгеньевич}

Есть ии у государства как института определяющий признак, отличающии его от других институтов? Может быть, совокупность признаков?

Почему актуален вопрос об определяющих признаках института государства? В 1990-е эти признаки могли представлять интерес с точки зрения фиксации эрозии института государства под влиянием процессов глобализации экономики, денационализации правящих элит. Более того, институт государства стал восприниматься как тормоз прогрессивных структурных сдвигов. Как писал И. Валлерстайн, «если мы хотим достаточно решительно повлиять на ход переживаемых нами серьезных сдвигов во всей миросистеме, с тем чтобы они происходили более в одном направлении, нежели другом, здесь государство не является главной движущей силой прогресса. На деле оно скорее представляет собой главное препятствие на этом пути» [1. - C. 9].

Государство как социальный институт это не только форма организации общества на определенной территории, но и форма выстраивания отношений с другими обществами. На фоне глобализации нормой действия национальных государств представлялась последовательная передача полномочий внешним институтам. Пандемия показала, что на чужие плечи заботу о гражданах переложить не удастся.
Цифровизация общества - это новые возможности и для выявления интересов общества, организации публичной власти, и для оказания государственных услуг. Вместе с тем цифровизация бросает новый вызов институту государства. Некоторые пользователи Интернета чувствуют себя скорее гражданами мира, чем конкретной страны с ее нормами и аппаратом принуждения.

Гражданин мира - это не только фигура речи. Существует Всемирное правительство граждан мира (World Service Authority WSA). Выдаваемый WSA паспорт гражданина мира основывается на пунктах (1) и (2) статьи 13 Всеобщей декларации прав человека, принятой ООН 10 декабря 1948 г. В статье 13 (1) Всеобщей декларации прав человека говорится: «Каждый человек имеет право на свободу передвижения и проживания в границах каждого государства», а статья 13 (2) гласит: «Каждый человек имеет право покинуть любую страну, в том числе [свою собственную] и вернуться в [свою страну]».

Хотя определение института государства остается дискуссионным, многие ориентируются на четыре признака государства как субъекта международного права, которые зафиксированы в 1933 г. в Конвенции Монтевидео:

- постоянное население;

- собственное правительство;

- способность к вступлению в отношения с другими государствами;

- определенная территория.

Возможно, что такие характеристики являются удобными ориентирами для международного признания государств. Если же под собственным правительством понимать правительство, призванное реализовывать волю только своих граждан, то на практике наблюдаются ситуации, когда власти страны действуют/бездействуют под влиянием других государств. Такое влияние может, в частности, ограничивать способность к вступлению в отношения с другими государствами. 
Некоторые государства демонстрируют стремление к экстерриториальному применению национального законодательства не только к своим гражданам и юридическим лицам. Такую практику демонстрируют прежде всего США.

Другое дело, когда действие национального закона не ограничивается территорией страны, но распространяется только на ее граждан. Так, Федеральный закон Российской Федерации «О воинской обязанности и военной службе» действует также в отношении российских военнослужащих, находящихся за границей.

Государство - это социальный институт, который таким образом регулирует распределение экономических ресурсов и социальных позиций, что обеспечивает воспроизводство данной социальной системы. Очевидно, что статус гражданина мира не является источником средств существования для простых граждан. В ходе исторического развития меняется характер как регулируемых государством социальных позиций, так и важнейших ресурсов, но принципиальное значение имеют преемственность и воспроизводство определенной идентичности общества. Способность обеспечить такую преемственность - определяющии признак заслуживающего места $b$ истории состоявшегося государства.

Как соотносятся между собой две фрункиии государства: производство общественных благ и принуждение?

Ряд общественных благ, в частности защита от внешних угроз, требует некоторой централизации ресурсов. В какой степени эта централизация сопровождается принуждением, зависит от морали общества. Есть общественные блага, например, тишина в ночное время, соблюдение чистоты в общественных местах, которые в принципе могут быть обеспечены децентрализованным образом. В этом случае вопрос о мерах принуждения становится актуальным лишь тогда, когда не все уважают интересы окружающих.

Пандемия побуждает вспомнить о так называемых мериторных благах, полез- ность которых потребители могут недооценивать, не осознавать в полной мере. Соблюдение индивидуальных профилактических мер предстает своего рода общественным благом, поскольку положительный эффект от них в виде сдерживания эпидемии достается всем. К пренебрегающим заботой о собственном здоровье и окружающих оправданы стимулирующие меры. При их недостаточности принуждение становится средством обеспечения общественного блага.

Возможен ми такой принции управления, как народовластие?

О народовластии или демократии говорится как о принадлежности всей полноты власти народу. Однако принадлежность и использование - это две большие разности. Одно дело, если суверенитет народа реализуется в коллективном принятии им решений по принципиальным вопросам (прямая демократия), другое - если говорится об особой форме государственного правления, при которой власть осуществляют представители народа.

Среди критиков демократии много крупных исторических фигур, начиная с Сократа, выступавшего против практики выборов должностных лиц по жребию и опасавшегося, что власть получат недостойные ее. «По отношению к государству положение самых порядочных людей настолько тяжелое, что ничего не может быть хуже... Для большинства бесполезны люди, выдающиеся в философии», - отмечается в диалоге Платона «Государство». В книге шестой этого диалога фактически содержится предупреждение о возможности обретения власти теми, кто на пути к ней потакает не самым лучшим вожделениям большинства.

Среди принципов демократического правления фигурирует подчинение меньшинства большинству. Если меньшинство не получает некоторой компенсации, для него такая ситуация фактически оказывается диктатурой большинства, а не самоуправлением народа. 
Элинор Остром, лауреат премии по экономике памяти Альфреда Нобеля за 2009 г., в качестве условия длительного существования самоуправляемых институтов указывает на то, что индивиды имеют общее прошлое и рассчитывают иметь общее будущее. Индивидам важно поддерживать свою репутацию надежных членов сообщества. Репутация человека, держащего слово, человека честного и надежного, которую он имеет в рамках своей площадки, представляет собой ценный актив. Стремление следовать нормам должного поведения усиливается разумным стремлением следовать своим собственным долгосрочным интересам. Ни в одной из описанных Э. Остром ситуаций участники не различались между собой в зависимости от принадлежащих им активов, квалификации, знаний, этнической принадлежности, расы и других характеристик, которые могли бы сильно разделить группу индивидов, составляющих общину [6].

Важным аспектом самоуправления в исследовании Э. Остром предстает надзор за соблюдением правил, установленных самоуправляемой группой. При этом отмечается, что если индивид начинает осуществлять надзор за другими членами группы и обнаруживает, что большинство из них большую часть времени придерживаются правил, то он в большей мере будет склонен придерживаться стратегии, согласованной с действиями других. Принятие согласованной стратегии увеличивает вероятность осуществления мониторинга, а наличие мониторинга увеличивает шансы принятия участниками согласованной стратегии [6].

Среди условий, оказывающих воздействие на реализацию возможностей самоорганизации, Э. Остром указывает, в частности, общность интересов, наличие среди участников таких, которые обладают сильными лидерскими качествами или иными активами. По ее мнению, одна из предпосылок выбора правил самоуправления - большинство присваивателей разделяют общие нормы взаимного поведения и доверия, что может быть использовано в качестве начального социального капитала [6]. Исследование Э. Остром позволяет прийти к выводу, что система народовластия в государственных масштабах тем реальнее, чем меньше расхождение интересов по принципиальным вопросам между гражданами страны, чем сильнее они дорожат своей репутацией.

Большое значение при самоуправлении имеет спектр охватываемых им задач. Достижение консенсуса облегчается, когда этот спектр ограничивается задачами, по которым позиции сторон достаточно близки, а возможные расхождения не угрожают устойчивости системы.

При анализе работоспособности прямой демократии привлекает внимание опыт Швейцарии. Успешность этого опыта может быть связана с тем, что все 26 швейцарских кантонов обладают большой самостоятельностью в решении внутренних проблем, а полномочия центрального правительства сосредоточены на внешней и экономической политике.

По Конституции Швейцарии (в редакции от 18 апреля 1999 г.), «кантоны суверенны, поскольку их суверенитет не ограничен Союзной конституцией; они осуществляют все права, которые не переданы Союзу» (ст. 3). Вторая глава Конституции предусматривает обязательные и факультативные референдумы. В соответствии со статьей 141 условия факультативного референдума следующие: «1. По требованию 50000 избирателей или восьми кантонов выносятся на голосование народа: а) союзные законы; b) объявленные срочными союзные законы, срок действия которых превышает один год; с) федеральные решения, поскольку это предусмотрено Конституцией или законом; d) международноправовые договоры, которые: 1) являются бессрочными и нерасторжимыми; 2) предусматривают вступление в международную организацию; 3) вводят многостороннюю унификацию права. 2. Союзное Собрание может выносить на факультатив- 
ный референдум также иные международно-правовые договоры».

В каком направлении происходит эволюиия государства? В эпоху циирровизации и глобамизации государства укрепляются или начинают модифицироваться $b$ сторону сохранения формы при потере содержания?

Перспективы государства в эпоху цифровизации неоднозначны. С одной стороны, новые технологии расширяют возможности для осуществления прямой демократии. С другой стороны, цифровые технологии способны стать инструментами превращения государства в «большого брата». Кинематограф уже откликнулся на такую опасность рядом фильмов-антиутопий.

Цифровизация позволяет собрать детальные сведения о каждом человеке, его контактах и запросах. При этом цифровые технологии дают возможность индивидуализировать информацию, поступающую отдельным гражданам, что уже сейчас наблюдается при интернет-рекламе. Все это открывает перспективу манипулирования человеческим поведением, вплоть до реальной имитации свободного выбора при принятии решений государственной важности. Риски соединения технологий обработки больших данных и искусственного интеллекта уже стали объектом осмысления специалистами [5].

Есть определенная логика в том, что именно в Японии с весьма однородным населением, испытывающим страх «потери лица» при оппортунистическом поведении, в цифровых технологиях видят не только основу для радикальных изменений в производстве («Индустрия 4.0»). Япония выступила пионером разработки стратегии «Общество 5.0» (Society 5.0 или Super Smart Society), которая должна привести к обновлению многих сфер общественной жизни.

Речь идет об обеспечении активного, творческого долголетия, о создании общества, где люди смогут вести разный образ жизни, реализовать свое понимание счастья. Говорится об обеспечении таких условий даже для живущих в отдаленных районах. С формированием общества 5.0 связывают снижение социально-экономического неравенства, переход к более равномерному распределению богатства и информации ${ }^{1}$.

Насколько серьезно пандемия изменила систему политических и экономических отношений между государствами?

Пандемия показала, что квазиинтеграция государств не обеспечивает эффективного маневрирования ресурсами при возникновении кризисных ситуаций. Это особенно заметно на фоне успехов Китая, где врачи со всей страны были своевременно направлены в Ухань, оказавшийся основным очагом новой эпидемии.

На первый план в условиях кризиса выходит ответственность государственной власти перед своими собственными гражданами. Как следствие, глобальный кризис способен привести к сопоставлению плюсов и минусов конкретных форм участия в соответствующих интеграционных структурах.

Другое дело, что ревизия, а тем более демонтаж этих структур чреваты столь неопределенными последствиями, столь большими рисками, что такое развитие событий маловероятно. Активными противниками демонтажа будут основные бенефициары интеграции. Более того, по инициативе ведущих участников для продвижения их интересов возможен пересмотр интеграционных отношений. Так, США добились замены договора NAFTA новым соглашением USMCA. Оно обеспечивает расширение доступа американским фермерам на канадские рынки, ухудшает условия для мексиканских автопроизводителей. Кроме того, USMCA усиливает защиту интеллектуальной собственности, что выгодно прежде всего США².

1 URL: https://www.keidanren.or.jp/en/policy/2018/ 095.html

2 URL: https://www.nbcnews.com/business/economy/ trump-signs-usmca-trade-deal-replace-nightmare-naftan1125526 
Как показывает практика, в современном мире количество государств увеличивается, когда в этом заинтересованы некоторые великие державы.

\section{Устюжанина Елена Владимировна}

Есть ли у государства как института определяющий признак, отличающий его от других институтов? Может быть, совокупность признаков?

Прежде всего необходимо разграничить два понятия: государство в широком смысле слова (наиболее близкий синоним страна) и государство в узком смысле слова (правительство, верховная власть).

Согласно общепринятой точке зрения, государство в широком смысле слова - это объединение граждан и созданных ими организаций (лиц на языке юристов или социальных акторов на языке социологов), в основе которого лежат три признака:

- подчинение общим законам (правилам взаимодействия);

- суверенитет - независимость во внутренних делах и внешних отношениях;

- территориальная обособленность.

Ни один из этих признаков не является абсолютным.

Подчинение общим законам носит во многом условный характер и зависит от силы (слабости) государства в узком смысле слова. Так, например, в России в 90-е гг. прошлого века наблюдались такие явления, как парад суверенитетов (вплоть до приоритета региональных нормативных актов над федеральными) и приватизация насилия - создание многочисленных силовых структур, подчиняющихся региональной или бизнес-элите. Иными словами, верховная власть, по сути, не могла защищать ни свои законы, ни права и интересы своих граждан.

Если говорить о суверенитете как о независимости, то любая независимость (даже рыночных агентов) является условной. Во-первых, есть ограничения, которые накладывает на действия агентов метасистема (в случае государств - это система надконституционных (культурных) норм, а также решения международных институтов). Во-вторых, социальные акторы сами могут ограничивать свою самостоятельность взятыми на себя эксплицитными или имплицитными обязательствами. В-третьих, нельзя не учитывать феномен разной переговорной силы сторон. Работник может «добровольно» соглашаться работать по 16 часов в сутки, чтобы прокормить семью. А государство может добровольно голосовать так, как просит «старший товарищ».

Территориальная обособленность также не является безусловным признаком государства, поскольку в эти рамки не укладываются государства, которые держатся на самоотождествлении некоторой группы людей. В качестве примеров таких образований можно привести Израиль до середины XX в., Польшу после трех разделов, запрещенную в России организацию «Исламское государство». И нужно сказать, что два первых примера показали возможность существования государства в уме (душе) людей, считающих себя его подданными, в течение очень длительных периодов времени.

Государство в узком смысле слова - это верховный агент, орган управления, который:

- обеспечивает стабильные условия функционирования поля взаимодействия социальных акторов, прямо или косвенно подпадающих под его юрисдикцию (управление на основе нормативной координации). Под понятием «поле взаимодействия» понимается система организации коммуникации социальных акторов, обладающая такими характеристиками, как относительно стабильный набор участников, общие правила взаимодействия и наличие той или иной формы принуждения к исполнению этих правил [2];

- охраняет социальные и территориальные границы этого поля путем выстраивания отношений с внешним миром;

- обладает эксклюзивными правами:

а) устанавливать общие, обязательные для всех участников подконтрольного по- 
ля взаимодействия, правила поведения (нормативная координация);

б) централизованно, опираясь на установленные им самим общие правила, перераспределять ресурсы, в частности, путем изъятия части имущества, принадлежащего другим агентам (трансакции рационирования);

в) осуществлять внеэкономическое принуждение вплоть до лишения граждан свободы и других личных прав (применение легитимного насилия);

г) разрешать правовые коллизии (сnеизификация и защита прав).

В отличие от признаков государства в широком смысле слова функции государства как верховной власти гораздо более аутентичны.

Как соотносятся между собой две функици государства: производство общественных благ и принуждение?

Государство как оператор поля взаимодействия всегда предстает в двояком обличии. Каким бы демократическим или, наоборот, деспотическим ни было государство как верховный агент, оно всегда выступает одновременно в двух противоречивых ролях:

- регулятора, устанавливающего обязательные общие правила взаимодействия, и актора, участвующего в самом взаимодействии;

- агентства по производству общественных благ и аппарата принуждения;

- продукта общественного договора и результата внутреннего и/или внешнего насимия;

- института снятия социальной напряженности (как необходимого условия противостояния внешним врагам) и института защиты интересов владельцев ключевых ресурсов (господствующего класса);

- оседлого бандита (грабителя, дающего возможность обираемым вассалам приумножать свое имущество, чтобы платить дань) и патрона, заботящегося о безопасности своих подданных и неприкосновенности подконтрольной территории;
- бюрократического аппарата как искателя административной ренты и организаиции, предоставляющей услуги специфоикации и зашичты прав;

- сочиального института, призванного обеспечивать самоидентификацию граждан через формирование общей системы смыслов (общность национальных, религиозных, региональных, культурных интересов), и политического института как системы контроля над деятельностью своих подданных.

Иными словами, государство как верховный агент представляет собой диалектическое единство противоречий. Основные различия между разными типами государств проходят по линии противоборства двух направлений его деятельности способа реализации общественного согласия относительно общих целей функционирования, с одной стороны, и способа разрешения конфликтов интересов (борьбы за ресурсы и борьбы за власть) - с другой.

C точки зрения более общего контекста - это борьба между двумя имманентными целями функционирования любой системы: развитием и самосохранением. При этом развитие, как правило, базируется на более или менее созидательном разрушении, а самосохранение - на установлении баланса интересов (в частности, путем ограничения чьих-то возможностей экспансии), а также консервации рутин и принципов сосуществования, доказавших свою эффективность в прошлом,

Возможен яи такой принциип управления, как народовластие?

Народовластие возможно и эффективно в относительно небольших, однородных образованиях, состоящих из людей, обладающих схожими интересами.

Еще один аспект проблемы народовластия связан с историческими закономерностями развития человеческих сообществ. Практически все известные истории общества проходили в своем развитии различные формы управления: и авторитарные, вплоть до деспотии, и демократические, 
включая прямую и представительную демократию. Вопрос эффективности этих форм был теснейшим образом связан с основаниями их возникновения - естественными (пусть даже путем революционных преобразований) или навязанными извне.

И тут мы прямо подходим к введенному А. А. Зиновьевым понятию колониальной демократии: «Колониальная демократия не есть результат естественной эволюции колонизируемой страны в силу внутренних условий и закономерностей ее социально-политического строя. Она есть нечто искусственное, навязанное этой стране извне и вопреки ее исторически сложившимся тенденциям эволюции... Стране навязываются внешние атрибуты западной политической системы: многопартийность, парламент, свободные выборы, президент и т. п. Но они тут являются лишь прикрытием режима...» [3. - С. 74] Иными словами, политические институты, заимствованные извне и не подкрепленные ни культурными традициями, ни необходимыми для их укоренения переходными институтами догоняющего развития [7], оказываются имитацией.

Отдельно необходимо остановиться на таком необходимом условии настоящего народовластия, как национальная культура. Если в традиционном западном мире многие коренные жители соответствующих стран понимают свободу как деятельное участие в осуществлении народовластия - связывают народовластие не только с правами, но и прежде всего с обязанностями (в частности, обязанностью соблюдать те самые правила игры, о которых они договорились), то в странах с альтернативными культурными традициями народовластие трудноосуществимо в силу совершенно иного понимания таких феноменов, как свобода и доверие.

Начнем со свободы. Ее можно понимать как:

1) совокупность признаваемых всеми прав и обязанностей, установленных на основе консенсуса интересов всех участников взаимодействия (операционные пра- вила и правила коллективного выбора по Э. Остром);

2) персональное право пренебрегать несправедливыми с точки зрения актора правилами (воля);

3) пространство господства (культурного, экономического, политического) одних акторов над другими (свобода как привилегия избранных).

Очевидно, что вторая и третья трактовки свободы не создают предпосылок для реального народовластия.

Доверие также можно трактовать поразному. Во-первых, как вертикальное (вера сателлита в превосходство и защиту патрона) или как горизонтальное (уверенность в порядочности, доброжелательности и помощи со стороны других людей) отношение. Во-вторых, в зависимости от области распространения и градации данного отношения - кто именно попадает в круг своих и как выстраивается взаимное расположение этих кругов по степени близости. Для понимания значимости данного критерия достаточно вспомнить протесты дальневосточного края против «московского диктата». Понятно, что чем сильнее традиции вертикального и градационного доверия, тем меньше возможностей для осуществления народовластия.

В каком направлении происходит эволюиия государства? В эпоху циифровизации и глобамизации государства укрепляются или начинают модифичииоваться В сторону сохранения формы при потере содержания?

В настоящее время происходят два взаимосвязанных процесса - дробление государств как относительно самостоятельных субъектов международного права и объединение государств в форме союзов (сетей) с потерей участниками сети части своих функций, начиная от производства общественных благ и заканчивая нормотворчеством [9].

Дробление государств обусловлено стремлением к более четкой самоидентификации на основе национального, религиозного, регионального или культурного самосознания. В этом смысле можно гово- 
рить о государствах как о культурных пространствах - территориях смыслов. Объединение (глобализация) представляет собой прямое следствие таких процессов, как интернационализация хозяйственной и финансовой деятельности, а также цифровизация, снимающая многие территориальные барьеры взаимодействия.

В этих условиях государство как феномен не остается неизменным. Изменяются его основные функции. Некоторые из них передаются на более низкий уровень управления (федерации и конфедерации), другие - на более высокий уровень (международные политико-экономические союзы). Происходят одновременно делегирование и уступка полномочий как вниз, так и вверх. Вместе с тем усиливаются две основные функции государства - обеспечение потребности людей в самоидентификации и принуждение (легитимное насилие).

Насколько серьезно пандемия изменила систему политических и экономических отношений между государствами?

Последствия пандемии для мирового сообщества можно разделить на две группы: внешние (отношения между государствами) и внутренние (перестройка системы отношений власти и общества). В обоих случаях, к сожалению, приходится констатировать явное усиление административно-оборонительных функций в ущерб гуманитарным.

Пандемия еще раз наглядно продемонстрировала стирание национальных границ как барьеров распространения кризисов. Раньше мы понимали, что глобализация все больше и больше разрушает экономические и финансовые границы между странами. Мировой рынок товаров и услуг, мировой финансовый рынок, транснациональные корпорации и между- народные сети создания стоимости породили риски экономического и финансового «заражения» мира. Теперь мы наглядно увидели отсутствие границ и для распространения страшных заболеваний.

В этих условиях у международного сообщества было два выхода: бороться с бедой вместе, в том числе создавая международные консорциумы для оказания лечебной, профилактической и фармацевтической помощи населению, или усиливать территориальную и политическую сегрегацию. К сожалению, пока государства выбрали второй путь.

Еще более жесткой оказалась внутренняя политика: тотальная электронная слежка за населением, ограничение права передвижения, отлучение от работы, принудительные медицинские осмотры и т. д. Понятно, что все эти меры предпринимались под лозунгом сдерживания распространения болезни, но раз начав, трудно остановиться.

Цифровые базы данных уже сформированы, навыки ограничения прав отработаны, способы решения проблем апробированы. Под вполне гуманитарными знаменами можно продолжать проводить антигуманистическую политику, прежде всего на рынке труда, в сферах образования и здравоохранения.

Фантастические прогнозы о создании двух систем образования - очной и дистанционной (для большинства населения) уже начинают постепенно реализовываться. А фактический запрет на преподавание людям старше 65 лет означает не только принудительное лишение людей профессии, но и фактическое уничтожение академического сообщества. Правда, всегда существует надежда, что маятник может качнуться в другую сторону.

\section{Список литературы}

1. Валлерстайн И. После либерализма. - М. : Едиториал УРСС, 2003. 
2. Дементъељ В. Е., ЕВсюков С. Г., Устюжанина Е. В. Гибридные формы организации бизнеса: к вопросу об анализе межфирменных взаимодействий // Российский журнал менеджмента. - 2017. - Т. 15. - № 1. - С. 89-122.

3. Зиновъев А. А. Гибель «Империи зла» (очерк российской трагедии) // Социологические исследования. - 1995. - № 4. - С. 74-81.

4. Лоренц К. Оборотная сторона зеркала. Восемь смертных грехов цивилизованного человечества. - М. : АСТ, 2019.

5. Маршалко Г. Развитие Big Data, нейротехнологий, искусственного интеллекта, блокчейна, IоT и сенсорики: риски и угрозы национальной безопасности. - URL: https:// www.tbforum.ru/blog/bigdata-neyrotekhnologii-iskusstvennyy-intellekt-blokcheyn-iot-isensorika-riski-i-ugrozy-natsionalnoy-bezopasnosti

6. Остром Э. Управляя общим: эволюция институтов коллективной деятельности. М. : ИРИСЭН : Мысль, 2010.

7. Полтерович В. М. Институциональные реформы и гражданская культура // Историческая и социально-образовательная мысль. - 2016. - Т. 8. - № 2-2. - С. 225-238.

8. Фукуяма Ф. Сильное государство: Управление и мировой порядок в XXI веке. - М. : АСТ : АСТ МОСКВА : ХРАНИТЕЛЬ, 2006.

9. Ханна П. Коннектография. Будущее глобальной цивилизации. - М. : Манн, Иванов и Фербер, 2019.

\section{References}

1. Wallerstein I. Posle liberalizma [After Liberalism, monograph]. Moscow, Editorial URSS, 2003. (In Russ.).

2. Dementev V. E., Evsyukov S. G., Ustyuzhanina E. V. Gibridnye formy organizatsii biznesa: $\mathrm{k}$ voprosu ob analize mezhfirmennykh vzaimodeystviy [Hybrid Forms of Business Organization: The Interfirm Cooperation Perspective]. Rossiyskiy zhurnal menedzhmenta [Russian Management Journal], 2017, Vol. 15, No. 1, pp. 89-122. (In Russ.).

3. Zinovev A. A. Gibel «Imperii zla» (ocherk rossiyskoy tragedii) [The Demise of "The Evil Empire" (An essay on Russian tragedy)]. Sotsiologicheskie issledovaniya [Social Researches], 1995, No. 4, pp. 74-81. (In Russ.).

4. Lorents K. Oborotnaya storona zerkala. Vosem smertnykh grekhov tsivilizovannogo chelovechestva [Behind the Mirror: A Search for a Natural History of Human Knowledge, monograph]. Moscow, AST, 2019. (In Russ.).

5. Marshalko G. Razvitie BigData, neyrotekhnologiy, iskusstvennogo intellekta, blokcheyna, IoT i sensoriki: riski i ugrozy natsionalnoy bezopasnosti [Development of BigData, Neurotechnologies, Artificial Intelligence, Blockchain, IoT and Sensors: Risks and Threats to National Security]. (In Russ.) Available at: https://www.tbforum.ru/blog/bigdataneyrotekhnologii-iskusstvennyy-intellekt-blokcheyn-iot-i-sensorika-riski-i-ugrozynatsionalnoy-bezopasnosti

6. Ostrom E. Upravlyaya obshchim: evolyutsiya institutov kollektivnoy deyatelnosti [Governance the Commons. The Evolution of Institutions for Collective Action, monograph]. Moscow, IRISEN, Mysl, 2010. (In Russ.).

7. Polterovich V. M. Institutsionalnye reformy i grazhdanskaya kultura [Institutional Reforms and Civic Culture]. Istoricheskaya i sotsialno-obrazovatelnaya mysl [Historical and SocialEducational Ideas], 2016, Vol. 8, No. 2-2, pp. 225-238. (In Russ.).

8. Fukuyama F. Silnoe gosudarstvo: Upravlenie i mirovoy poryadok v XXI veke [StateBuilding: Governance and World Order in the 21st Century, monograph]. Moscow, ACT : ACT MOSKVA : KHRANITEL, 2006. (In Russ.). 
9. Khanna P. Konnektografiya. Budushchee globalnoy tsivilizatsii [Connectography. Mapping the Future of Global Civilization, monograph]. Moscow, Mann, Ivanov i Ferber, 2019. (In Russ.).

\section{Сведения об авторах}

\section{Валерий Леонидович Макаров}

доктор физико-математических наук, профессор, академик РАН, научный руководитель ЦЭМИ РАН.

Адрес: ФГБУН «Центральный экономикоматематический институт Российской академии наук», 117418, Москва,

Нахимовский проспект, д. 47.

E-mail: makarov@cemi.rssi.ru

\section{Анатолий Николаевич Козырев}

доктор экономических наук, научный руководитель научного направления «Математические и компьютерные модели, экономика знаний, инструменты и методы» ЦЭМИ РАН.

Адрес: ФГБУН «Центральный экономикоматематический институт Российской академии наук», 117418, Москва,

Нахимовский проспект, д. 47.

E-mail: kozyrevan@yandex.ru

\section{Виктор Евгеньевич Дементьев}

чл.-корр. РАН, доктор экономических наук, профессор, руководитель научного направления «Макроэкономика и институциональная теория» ЦЭМИ РАН.

Адрес: ФГБУН «Центральный экономикоматематический институт Российской академии наук», 117418, Москва,

Нахимовский проспект, д. 47.

E-mail: dementev@cemi.rssi.ru

\section{Елена Владимировна Устюжанина}

доктор экономических наук, доцент, профессор кафедры экономической теории РЭУ им. Г. В. Плеханова; главный научный сотрудник ЦЭМИ РАН.

Адрес: ФГБОУ ВО «Российский экономический университет имени Г. В. Плеханова», 117997,

Москва, Стремянный пер., д. 36; ФГБУН «Центральный экономикоматематический институт Российской академии наук», 117418, Москва, Нахимовский проспект, д. 47. E-mail: dba-guu@yandex.ru

\section{Information about the authors}

\section{Valery L. Makarov}

Doctor of Phys. and Math. Sciences, Professor, RAS Academician, Scientific Adviser of CEMI RAS. Address: Central Economics and Mathematics Institute of RAS, 47 Nakhimovsky Avenue, Moscow, 117418, Russian Federation. E-mail: makarov@cemi.rssi.ru

\section{Anatoly N. Kozyrev}

Doctor of Economics, Head of scientific direction "Mathematical and Computer Models, Knowledge Economics, Tools and Methods" CEMI RAS.

Address: Central Economics and Mathematics Institute of RAS, 47 Nakhimovsky Avenue, Moscow, 117418, Russian Federation. E-mail: kozyrevan@yandex.ru

\section{Viktor E. Dementiev}

Corresponding member of RAS, Doctor of Economics, Professor, Head of scientific direction "Macroeconomics and Institutional theory" CEMI RAS.

Address: Central Economics and Mathematics Institute of RAS, 47 Nakhimovsky Avenue, Moscow, 117418, Russian Federation.

E-mail: dementev@cemi.rssi.ru

\section{Elena V. Ustyuzhanina}

Doctor of Economics, Assistant Professor, Professor of the Department for Economic Theory of the PRUE; Chief Researcher of the CEMI RAS. Address: Plekhanov Russian University of Economics, 36 Stremyanny Lane, Moscow, 117997, Russian Federation; Central Economics and Mathematics Institute of RAS, 47 Nakhimovsky Avenue, Moscow, 117418, Russian Federation. E-mail: dba-guu@yandex.ru 